\title{
Vulnerabilities Faced by Women Widowed by Kedarnath Disaster: An explorative case study
}

\author{
Kishore Mohan, Yamuna S Bonin \\ Centre for Gender Equality and Women Empowerment, \\ Amrita Vishwa Vidyapeetham, Amritapuri, Clappana P. O.,Kollam - 690525, Kerala, India \\ kishoremohan777@gmail.com, yamuna.bonin@ammachilabs.org \\ $+919526365323$
}

\begin{abstract}
This paper is aimed at exploring the vulnerabilities of women widowed during the Uttarakhand floods of India in 2013. Generally, widows in the Northern States of India, are perceived as a second-class citizen and is usually associated with social neglect, isolation, restrictions and poverty. The study consisted of 20 women who lost their husband in the floods. The results indicate that they are facing financial difficulties and profound helplessness. Their economic concerns primarily revolved around providing primary education and decent nutrition for their children. Governmental compensation and pension were reported to be insufficient to cover daily needs.
\end{abstract}

Keywords: Widowhood; Vulnerability; Disaster; Floods

eISSN: 2398-42870 2020. The Authors. Published for AMER ABRA cE-Bsby e-International Publishing House, Ltd., UK. This is an open access article under the CC BYNC-ND license (http://creativecommons.org/licenses/by-nc-nd/4.0). Peer-review under responsibility of AMER (Association of Malaysian Environment-Behaviour Researchers), ABRA (Association of Behavioural Researchers on Asians) and cE-Bs (Centre for Environment-Behaviour Studies), Faculty of Architecture, Planning \& Surveying, Universiti Teknologi MARA, Malaysia. DOI: https://doi.org/10.21834/ebpj.v5iSI3.2530

\subsection{Introduction}

The 2013 North India floods was recorded to be one of the biggest catastrophes in India after the 2004 Indian Ocean Tsunami. The floods affected three Indian States: Uttarakhand, Himachal Pradesh and Uttar Pradesh and the neighboring country of Nepal. More than $89 \%$ of the casualties were reported in Uttarakhand (India raises flood death toll, 2013; Kumar, 2013). For four consecutive days, from June 14 - 17, 2013, a water deluge of heavy rainfall and melting snow caused torrential floods and avalanches. The recorded rainfall was almost five times the normal benchmark for the region's precipitation (Uttarakhand: Rescue efforts, 2013). The India Meteorological Department broadcasted repeated advisories, predicting heavy rains, which were ignored by the local residents. The resultant loss of life and property was enormous: 4,200 villages were affected and 5,748 people perished. Approximately 300 women were widowed in the aftermath of the 2013 floods in the Ukhimath Tehsil of the Rudraprayag district, in Uttarakhand. The floodaffected widows received governmental support for 500,000 INR (approximately 7,400 USD) as compensation, monthly widow's pension and a cow. This paper intends to explore the situation of the widowed women, five years since the disaster. It strives to contribute to the research on this target population who are understudied in social science research, according to Chandra (2011) and Bhattacharyya (2017).

eISSN: 2398-4287@ 2020. The Authors. Published for AMER ABRA cE-Bsby e-International Publishing House, Ltd., UK. This is an open access article under the CC BYNC-ND license (http://creativecommons.org/licenses/by-nc-nd/4.0/). Peer-review under responsibility of AMER (Association of Malaysian Environment-Behaviour Researchers), ABRA (Association of Behavioural Researchers on Asians) and cE-Bs (Centre for Environment-Behaviour Studies), Faculty of Architecture, Planning \& Surveying, Universiti Teknologi MARA, Malaysia. DOI: https://doi.org/10.21834/ebpj.v5iSI3.2530 


\subsection{Widowhood in India}

The number of widows in India is steadily increasing. According to the Census of India data, the proportion of widows raised from $0.7 \%$ of the population in 2001 to $4.6 \%$ in 2011 . This growth may be explained by the improved life expectancy of women and the traditional age difference between spouses (Shiva Kumar, 2015). The treatment of widowhood in India is associated with social neglect, isolation, restrictions and economic poverty.

\subsection{Sociocultural Biases and Discriminations}

The sociocultural perception of widowhood carries pangs of discrimination and restriction, which negatively impact the lives of widows and their family relationships. Sahoo (2014) mentions that widows are usually considered as a bad omen for any happy occasion, such as wedding, childbirth or house warming and were excluded from these ceremonial, social events. The society believes that the widows will bring some misfortune to the family. Bhattacharyya (2017), adding to these social discriminations, mentioned that widows have to face social exclusions in income, job and service. He explains that widows face more difficulties than a widower, particularly in terms of remarriage and land property. He also warns that this social exclusion may take the extreme form of widows being disowned by the family members because they are seen as an economic burden and a threat inland inheritance cases. There were cases that the widows were killed even by the family members themselves in case if they raise the issue of family property.

Mohini Giri, a veteran activist for the women rights, depicted the plight of widows in India as a state of social death even among the higher caste. In Punjab, for instance, widows are referred to as prostitutes and married off to the husband's brother, in order to prevent rape (Sahoo, 2014). In Uttarakhand, some widows who do not live with any other male member in the family reported being scared about sexual abuse and violence when some drunk men knock on their doors at night. (Chakrabarty, 2018). Sahoo (2014) suggested that attempting to claim retribution for perpetrators places widows at high risk of physical and psychological violence because they have challenged the patriarchal norms of the society.

\subsection{Economic Deprivation}

Economic deprivation is a significant cause of widows' vulnerabilities. Chandrasekhar (2017) mentioned that widows are usually badly affected after the death of their spouse. He explains that in the Indian patriarchal society, men are the prime earners of the family, own property, do paid work and manage the finances of the family. Wadley (1995) also suggests that a Hindu woman is usually economically dependent on her husband for all her necessary living expenses. Therefore, widows generally have lower than average consumption level and higher than average poverty level (Dreze, 1997).

Despite the need for economic stability, social restrictions are likely to be imposed on the employment of widows. Rural areas are often ruled by conservative norms, which constrain widows to household chores and disapprove their lookout for jobs outside the home (Chandra, 2011). Chen (1997) highlighted that the proportion of working widows is comparably lower than married women because of their relatively older age. However, Chandra (2011) suggested that living conditions of young widows are better in urban areas than in rural areas, because access to jobs is easier based on educational qualifications. Sahoo (2014) showed that rural widows who migrate to the cities to seek better employment might end up in sexual trafficking rackets. If once they were trapped by the noises hand, then their chances of coming back to a healthy life are complicated. In the Western and North Western regions of India, widows were found to either work as labourers in their in-laws' farms or resort to begging or become destitute (Agarwal, 1998).

While access to and ownership of assets such as land is contributing to economic security, widows are often denied access to such resources. Arable land is an important resource which provides wealth and protection. Agarwal (1998), argued that widows who have proprietary rights to productive land have access to more opportunities such as cultivation, selling or mortgaging during economic downturn periods. Chen (1997) explains that widows are threatened with death and expulsion from their village in land disputes, even though the law gives them usage rights over their husband's property (in the absence of an adult son) or maintenance rights (in the presence of an adult son). Such reports substantiate that customary norms violate widows' rights.

\subsection{Impacts on children}

Widowhood has considerable impact on the children's well-being. Henry (2013) and Rani (2006) emphasizes the burden of being a single parent for widows, especially in Indian rural areas. Most of the women do not have the education and qualifications to find a job and, if they find, they must leave their children at home for going outside for work. They become very anxious about the future of their children and life. Rani (2006) added that widows' children have more chances to drop out from schools and go for work to contribute to the family income. This is affecting the average years of schooling. Sahoo (2014), reported that widows with inadequate economic means tend to marry off daughters at younger ages. They don't have any other aims in life except for the well-being of their children. Some widows in extreme poverty struggling to meet the ends opt to send their children to shelters or mission homes to ensure the nutrition and education of the children (Chakrabarty, 2018).

\subsection{Methodology}

Participants of the study consisted of 20 widows of the Garhwal division, west of Uttarakhand. The participants were randomly selected from the list of 296 widows (Rudraprayag District) based on geographical convenience. The study was conducted in the following seven villages within the Ukhimath block, located near Guptkashi in Kedarnath: Nala, Rudrapur, Devar, Chandrapuri, Thyudi, Khumera and Lamgaundi. This study is qualitative. Semi-structured interviews were administered to explore vulnerabilities faced by 
widows of the Kedarnath disaster. Interview questions were designed to develop an understanding of how women perceived impacts of the crash on their lives and their widowhood conditions. Follow-up questions also evaluated how the event triggered vulnerabilities in their lives. All of the interviews were recorded with informed consent from the respondents.

\subsection{Results}

The sample constituted of 25-60-year-old widows with an average age of 37 years old. Out of the 20 respondents, eight women are from the Brahmin and 12 from the Scheduled Caste (SC) community. Three widows did not attend school, but the rest of them have qualifications up to 8 th. In the hill region of Uttarakhand, above $60 \%$ of the workers are cultivating their land (compared to $24.6 \%$ in India) according to 2011 census data. The gender disparity is striking, showing the prime responsibility of women in fieldwork: nearly $80 \%$ of women workers are cultivating their land.

In comparison, only $40 \%$ of men workers are involved in this activity. In addition to household chores and farming duties, women's traditional and daily work includes collecting water, fuelwood and fodder for livestock. Respondents reported that each household has as a minimum of a 10-cent piece of farmland and a cow. Crops such as wheat, maize and groundnuts are commonly cultivated. The crops that they are cultivating is usually used for home consumption and sometimes if there's extra then they will sell it in the market. Standard livestock at home included oxen, cows, buffaloes, and goats. Milk from the livestock is either sold or consumed for the family's needs.

\subsection{Poverty}

Fifteen of the widows from the sample reported managing their lives on their own. They perform all the activities in their agricultural field. They mentioned, "I am working in my land. We survive with what we have", "I am doing everything alone". Fourteen widows received their husband's property. For the rest of the six widows, their family property has not been legally divided; it is still in the name of father-in-law or mother-in-law. In addition to fieldwork, two widows reported that they were employed (at the time of the study) in road construction projects. One respondent who is working said "I am doing nothing. Whenever there is road construction at that time, I will have work. Other than that, we don't have anything". One widow expressed the desire to get a job so that she can look after the kids: she stated, "I need one job. I want to provide for children education". Out of the 20 widows, six widows reported poverty as an issue, unable to meet the demands of daily life. Three of them said that there were no financial problems when the husband was alive, whereas now it is difficult. One widow responded "everything is a problem after the disaster. Every place there is a problem. If the husband is not there, then surely it is a problem. Children need education. I am trying to find solutions, but what to do?" For those 16 respondents who are having school-going children, meeting the children's nutrition and education needs were reported to be significantly challenging due to the lack of an alternative source of income. Widows stated "Who will help us? The children are small. They need education. Money is needed for that", "If the government provides some help for the education of the children by any means then it will be very helpful". One widow who felt helpless to provide for the children shared that she sent them to a care home. One widow who is living in the old house along with children said that she does not have the financial capability to repair cracks in the house.

\subsection{Meager Governmental Support}

Out of the 20 respondents, seven respondents told that the compensation amount, i.e. 500000 INR (approximately 7295 USD) given by the government, is not sufficient. Widows reported: "We got five lakhs but that finished. Now, what is there with us? Nothing", "They gave five lakhs for everyone at that time, but that is nothing. What will happen with that amount?" The respondents also receive a monthly government pension of about 1000 INR (approximately $15 \mathrm{USD}$ ). Only two widows reported that they have not yet received their pensions. They explained that in one case it is due to incorrect paperwork and in the other case, the village head was asking for a bribe. Six widows mentioned that the payments were not received regularly, sometimes the gap is up to 3 to 6 months. Widows reported: "The pension is not coming regularly. It will come after maybe 3 - or 6 - months' gap. Sometimes, it may come after six months, and we receive the amount for three months". Two widows also complained that this pension is not sufficient. "What will happen with the money (pension amount) that am getting? It's nothing".

Widows are also facing difficulties with their ration card status. Fourteen widows are Above Poverty Line (APL) ration cardholders, and 6 are Below Poverty Line (BPL) cardholders. APL status is given to those family who earns more than 27000 per year (approximately 395 USD). Widows reported that after their husband's death, they approached the Pradhan to change their APL ration card into BPL. They were denied with the excuse that the government had discontinued making BPL cards. However, women reported that this card might be useful for other benefits such as the payment of school fees. One woman explained: "We talked, but they (Panchayat officials) are saying that they are not making. We need that (BPL card) for getting a reduction in school fees. We did not get the BPL card". When we met with the Village Head, he explained that the BPL ration cards are not made any more and that widows should go to a Government Officer to get a certificate attesting that their income is below the poverty line.

\subsection{Familial support}

Out of the 20 widows, three of them have grown up and working sons. They don't have much financial problems compared to the other widows because the son is working and looking after the family matters. The natal family is composed of the widow's parents and siblings, the brother is culturally the main person likely to provide support and care for the entire family. Only three widows reported receiving some help from their brothers, which consists of paying school fees or some other minimal financial help. The rest 
of the widows testified that they did not receive any support from their families. One of the reasons was expressed as such: "Nothing. They cannot help. They (natal family members) have difficulty in meeting their needs," "Everyone got their own family to take care. They cannot extend their help to outside." The marital family is formed of the in-laws. Only two widows reported some help of the brothers-in-law in the form of vegetables. They explained it because of the geographical proximity of the brother-in-law's house.

\subsection{Hopelessness}

A few widows ( 3 of them) exhibited hopelessness during the interview session. The absence of their loved ones has created a big hole in their lives. Women said: "There is nothing left with us", "Nothing is there. There is nothing for the future", "Now we don't have anything".

\subsection{Discussion}

This explorative case study clearly reveals that women face economic difficulties despite their access and work in their husband's fields. Majority of the women do the cultivation of the crops alone or sometimes with the help of the family members. The women can't be productive similar to the level of the men in the field of cultivation. Most of the widows reported ownership of their land, whereas literature suggests that widows are usually deprived of this right. Allowing women to inherit may be a sign that Uttarakhand culture is more liberal. Another explanation may be related to women's prime responsibility in fieldwork. This status is likely to be a positive factor for coping, as Gupta (2016) explained that the occupational level indicates the degree of vulnerability.

However, the need for alternative livelihoods is even more important that Abhinash (2014) warned against the risk of economic relegation and Augustine (2014) advocated for improved livelihoods, community support and empowerment to better address survivors needs. The economic need shared unanimously by widows requires some improvements in governmental strategies. The compensation and pension amounts seem insufficient to address widows' hardship, specifically children's education and nutrition. Moreover, the delay in receiving governmental pensions weakens the quality of this support. Improved management and governance have the potential to address these needs. Mohanan, 2016, suggested using the COBIT 5 framework, a widely accepted, comprehensive IT governance and management framework, to develop the National Disaster Management Plan further. Indeed, defining objectives that suit stakeholders' conditions, especially survivors, along with an action plan is the responsibility of the governance. Using well known and recognized governance and management tools would ensure a more acute need assessment along with effective and timely interventions.

This study barely contains sensitive information which should be expected according to the available literature on the subject. Women are likely to open up on economic matters easily and financial difficulties, however, they won't speak much about social discriminations, restrictions and abuses. The collection of sensitive data would require the interviewer to be more familiar with the situation of these widows, speak in their language, Garhwali, and ideally be a woman. The interviewer being an outsider man, might be an inhibiting factor for women to share on their plight.

\subsection{Conclusion \& Recommendations}

The economic deprivation is the main post-disaster concern of widows. Almost all the widows struggle to look after their children's education and nutrition. They cannot expect much support from natal or marital families because the family members are busy with their own daily life and life's problems. Also, they are receiving little support and consideration from the government. The cultural settings in Uttarakhand make it easy for widows to access land ownership even though it is not customary practices in North India. Their deep-rooted occupational habits related to fieldwork and animal husbandry ensure their minimum survival needs, but it's not at all sufficient for meeting their extra needs. However, the strong feeling of hopelessness revealed in these interviews suggests that widows see no hope for their future; they feel helpless to provide good education to their children. This paper suggests that the postdisaster activities should be emphasized on livelihood diversification and sustainability to ensure economic stability to disaster victims. If the widow is involved in some livelihood activities in a group, it will provide her additional income and a place to speak and share her emotions. The government is responsible for implementing effective policies to ensure the welfare of the survivors. In this process, verifiable research data and participatory governance are instrumental in understanding the needs of the population and design interventions to meet these needs.

\section{Acknowledgements}

The authors are very much grateful to the Ammachi Labs and Centre for Women Empowerment and Gender Equality (CWE \& GE) for the help and guidance provided in completing the study.

\section{References}

Abhinash, P. V. M., Saivenkata Pavan, G., Prasad, G., and Sivasubramanian, G. (2014) Uttrakhand Disaster: Sustainability Relegated, in Disaster, Risk and Vulnerability Conference.

Agarwal, B. (1998). Widows versus daughters or widows as daughters? Property, land, and economic security in rural India. Modern Asian Studies, 32(1), 1-48. 
Augustine, J. and M., R. M. (2014). "Addressing the Needs of Disaster Survivors: Does Their Voice Matter?" International Journal of Social Work and Human Services Practice, vol. 2, pp. 43-49, 2014.

Bhattacharyya, R., \& Singh, S. (2017). Exclusion (and seclusion): geographies of disowned widows of India. GeoJournal, 1-18.

Chakrabarty, A. (2018, March 8). The continuing hardships of the widows of Uttarakhand, five years after the flash floods. The Indian EXPRESS. Retrieved from http://indianexpress.com

Chandra, A. (2011). The vulnerability of widows in India: Need for inclusion. International journal of social and economic research, 1(1), $124-132$.

Chen, M. A. (1997). Listening to widows in rural India. Women: a cultural review, 8(3), 311-318.

Dreze, J., \& Srinivasan, P. V. (1997). Widowhood and poverty in rural India: Some inferences from household survey data. Journal of Development Economics, 54(2) $217-234$

Gupta, P. and Inbanathan, A. (2016). "Surviving disasters: Vulnerability and coping in two villages of coastal Odisha (India)", Man in India, vol. 96, pp. $2913-2930$.

India raises flood death toll to 5700 as all missing persons now presumed dead. (2013, July 16). Retrieved from https://www.cbsnews.com/news/

Kumar, S. (2013, July 16) 5748 feared dead after India floods. Retrieved from www.iol.co.za

List of missing person widow. (2013, December 20). Retrieved from https://rudraprayag.gov.in/

Mohanan, C. and Menon, V., "Disaster management in India - An analysis using COBIT 5 principles", in GHTC 2016 - IEEE Global Humanitarian Technology Conference: Technology for the Benefit of Humanity, Conference Proceedings, 2016, pp. 209-212.

Rani, N. I. (2006). Childcare by poor single mothers: Study of mother-headed families in India. Journal of Comparative Family Studies, 75-91.

Sahoo, D. M. (2014). An analysis of widowhood in India: A global perspective. International Journal of Multidisciplinary and Current Research, 2.

Sivakumar, B. (2015, March 3) Massive spike in number of widows. Retrieved from https://timesofindia.indiatimes.com

Uttarakhand: Rescue efforts in full swing; 102 dead, 72000 stranded. (2013, June 18). Retrieved from https://archive.fo/Ou8BH

Varma, P. (2016). Abuse against Widowhood in India. The International Journal of Indian Psychology, 4(1),131-146.

Wadley, S. (1995). No longer a wife: Widows in rural north India. From the margins of Hindu marriage: Essays on gender, religion, and culture, 92-118. 